\title{
Value-At-Risk Analysis Using ARIMAX-GARCHX Approach For Estimating Risk Of Bank Central Asia Stock Returns
}

\author{
Felinda Arumningtyas ${ }^{1}$, Alan Prahutama ${ }^{2}$, Puspita Kartikasari ${ }^{3}$
}

Statistics Departement, Diponegoro University, Indonesia

\begin{tabular}{l}
\hline \hline Article Info \\
\hline Article history: \\
Received : 09-24-2021 \\
Revised : 10-29-2021 \\
Accepted : 10-31-2021
\end{tabular}

\section{Keywords:}

Stock;

VaR;

ARIMAX-GARCHX;

Heteroscedastic.

ABSTRACT
Before buying a stock, an investor must estimate the risk which will be received. VaR is one of the
methods that can be used to measure the level of risk. Most stock returns have a high fluctuation,
so the variant is heteroscedastic, which is thought to be caused by exogenous variables. The time
series model used to model data that is not only influenced by the previous period but is also influ-
enced by exogenous variables is ARIMAX. In contrast, the GARCHX model is used to obtain a more
optimal stock return data model with heteroscedasticity cases and is influenced by exogenous vari-
ables. This study uses the ARIMAX-GARCHX model to calculate the VaR of the stock returns of
PT Bank Central Asia Tbk. The exogenous variables used are the exchange rate return of IDR/USD
and the return of the JCI in the period January 3,2017 , to March 31,2021 . The best model chosen
is the ARIMAX(2,0,1,1)-GARCHX(1,1,1). VaR calculation is carried out with the concept of moving
windows with time intervals of 250,375 , and 500 transaction days. The results obtained at the $95 \%$
confidence level, the maximum loss obtained by an investor is $1,4 \%$.

Accredited by Kemenristekdikti, Decree No: 200/M/KPT/2020 DOI: https://doi.org/10.30812/varian.v5i1.1474

Corresponding Author:

This is an open access article under the CC BY-SA license.

Felinda Arumningtyas,

Statistics Departement, Diponegoro University.

Email: felindaarum@gmail.com

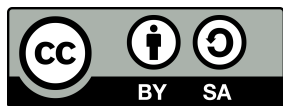

\section{A. INTRODUCTION}

Investment is one of the activities that can be done by the community to earn a profit. In the past year, public interest in investment activities has continued to increase (Azmi and Syaifudin, 2020). Based on a press release published by the Indonesia Stock Exchange (Monday/14/12/2020), the number of Indonesian capital market investors as of December 10, 2020, was 3.697.284 SID, up 48,82\% from 1,212,930 SID in the previous year. This is the highest increase in the history of the Indonesian capital market. In addition, IDX also said that stockholders in 2020 were dominated by domestic investors (Bursa Efek Indonesia, 2021). Stock is one type of security that is quite popular to be traded on the capital market. Because when compared to other investments, stocks allow investors to get a higher rate of return or profit in a relatively short time (high return). In addition to high returns, stocks also have a high-risk nature. Namely, stock prices can also drop rapidly, or their shares are delisted from the stock exchange so that they are for sale and purchase (Primajati, 2018). Of course, an investor expects a high return in their investment activities. But that means that he also must be prepared to face increased risks. So, before buying a stock, an investor must estimate the risks received (Tyas et al., 2019). One of the popular methods used to measure the level of risk is Value at Risk (VaR). Value at Risk measures risks by estimating the worst losses overtime at a certain level of confidence (Messaoud and Aloui, 2015). For investors, this measuring tool is important to determine the level of confidence that reflects the risk that must be considered in purchasing investments.

There are many methods of time series data. The most frequently used method is the Autoregressive Integrated Moving Average (ARIMA). ARIMA is widely used for time series data that follows a linear pattern and shows unsatisfactory results when the data being analyzed is data with noise disturbance or data that fluctuates extremely (Made et al., 2017). One example of data that 
fluctuates significantly is stock return data. Most stock return data has a high fluctuation, so the variant is heteroscedastic, caused by exogenous variables, one of which is the return on the IDR/USD exchange rate and the return on the JCI (Prastyo et al., 2018a). Therefore, we need a time series method that considers the effect of time and involves other variables called exogenous variables. This method is often called ARIMAX. Meanwhile, to produce a more accurate model for stock return data that is not homogeneous by including exogenous variables, the GARCHX method can be used. The risk estimation of stock returns in this study will be carried out using the Value at Risk method with the ARIMAX-GARCHX approach with the return of the rupiah exchange rate (IDR) against the US dollar (USD) and the JCI return as an exogenous variable (Darsyah and Nur, 2016). There is research about the measurement of risk estimation as done by Handayani et al. (2018), which analyzes Value at Risk using ARMAX-GARCHX to estimate the return risk of the property and real estate sub-sector. A similar study was also conducted by Ratih et al. (2018) in sub-sector banking. Both studies show the conclusion that calculation of Value at Risk (VaR) with ARMAX-GARCHX approach is suitable for use on stock return data that has volatility and is influenced by exogenous variables, namely the return of the IDR/USD exchange rate and the return of the JCI.

The data used in this study is the stock of PT. Bank Central Asia Tbk (BBCA) which is the only private bank among 6 Indonesian companies listed in the Global 2000 "The World's Largest Public Companies" released by Forbes (Wednesday/13/05/2020). In addition, Bank BCA is also listed as a bank to provide the best profit for investors. VaR calculation can be done using a moving window concept with time intervals of 250, 375, and 500 transaction days to obtain the same basic model with more optimal parameters (Prastyo et al., 2018b). The confidence level value is readjusted using the Cornish-Fisher expansion if the return data is not normally distributed.

\section{B. LITERATURE REVIEW}

\section{ARIMAX-GARCHX Modeling}

ARIMAX or Autoregressive Integrated Moving Average with Exogenous Variables is developing the ARIMA model by adding exogenous variables to the equation. The stages in the process of identifying the form of the ARIMAX model used in this study are to determine the order $(\mathrm{p}, \mathrm{d}, \mathrm{q})$ for the ARIMAX model, where the order $(\mathrm{p}, \mathrm{q})$ is obtained from the identification of stock return data using ACF and PACF plots. While the order of d shows the number of differencing processes. So the equation of the $\operatorname{ARIMAX}(\mathrm{p}, \mathrm{d}, \mathrm{q}, \mathrm{b})$ model can be written as:

$$
(1-B)^{d} \varnothing_{p}(B) Z_{t}=\mu+\theta_{q}(B) a_{t}+\beta_{1} X_{1, t}+\beta_{2} X_{2, t}+\ldots+\beta_{b} X_{b, t}
$$

$Z_{t}$ is the dependent variable at time $t, X_{1}, X_{2}, \ldots, X_{b}$ is an exogenous variable, $\mathrm{p}$ is denoted as the number of orders Autoregressive (AR), d number of differencing, q number of moving average orders (MA), and $b$ is the number of exogenous variables used.

In general, financial data has high volatility. Volatility occurs when the time series variance pattern is not stationary because the variance is not constant (Puspatika and Kusumawati, 2018). To produce an accurate model for financial data, it can be done by adding exogenous variables in the variance equation. The exogenous variables used are variables that have a correlation with time-series data in the volatility equation. One method that can be used to overcome this problem is the GARCHX. The GARCHX (p,q,b) model can be written as:

$$
\sigma_{t}^{2}=\omega+\sum_{i=1}^{p} \alpha_{i} a_{t-1}^{2}+\sum_{i=1}^{q} \beta_{j} \sigma_{t-j}^{2}+\sum_{l=1}^{b} \pi_{l} x_{l t}^{2}
$$

Before doing the modeling, the most basic requirement in the time series analysis is the stationary test. Time series data is said to be stationary if no increase or decrease is too striking, or it can be said that the data shows a constant pattern from time to time. The test used is the Augmented Dickey-Fuller test with the hypothesis:

$H_{0}:=0$ (there is a unit root or the data is not stationary)

$H_{1}:<0$ (no unit root or stationary data)

Significance Level : $\alpha$

Test Statistics :

$$
A D F_{v} \text { alue }=\frac{\hat{\delta}}{S E(\hat{\delta})}
$$




\section{Test Criteria :}

Reject $H_{0}$ if $A D F_{v}$ alue $\left.<A D F_{(} n,\right)$ or $p-$ value $<\alpha$.

In general, the time series method has several main steps in building the model; Identification, Estimation, and Diagnostics. With these three steps, first, the tentative model parameters are identified through the ACF and PACF graphs (Guha and Bandyopadhyay, 2016). After getting the model, we need to estimate and test the significance of the parameters. Maximum Likelihood Estimator (MLE) is one method that can be used for parameter estimation. After successfully estimating the parameters, the next step is to test the significance of the parameters for each model that is formed. Testing the significance of parameters on the $\mathrm{AR}(\mathrm{p})$ model is carried out with the hypothesis:

$H_{0}: \varnothing_{i}=0$ (parameter is not significant to the model)

$H_{1}: \varnothing_{i} \neq 0, i=1,2, \ldots, p$ (parameter is significant to the model)

Test Statistics:

$$
t=\frac{\hat{\varnothing}}{S E(\hat{\varnothing})}
$$

Test Criteria:

Reject $H_{0}$ if $|t|>t_{\left(\frac{\alpha}{2} ; n-p\right)}$ or $p-$ value $<\alpha$.

After the model parameters are significant, the next step is diagnostic checking which aims to find out whether the selected model is appropriate or not. This stage includes the residual independence test, normality test, and heteroscedasticity test. The last step that needs to be done is selecting the best model. In this study, the selection of the best model was carried out using the AIC (Akaike's Information Criterion) criteria with the following general equation:

$$
A I C(k)=n \ln \hat{\sigma}_{a}^{2}+2 k
$$

$\mathrm{k}$ is the number of parameters in the model. The minimum AIC value of all time series models that have been obtained can be used as the criteria for selecting the best model.

\section{Value-at-Risk}

The calculation of the VaR using the normal distribution approach is formulated as follows (Ratih et al., 2018):

$$
\left.V \hat{a} R_{t}()=\hat{\mu}_{t}+\hat{\sigma}_{t} F^{(}-1\right)(\alpha)
$$

With $\left.F^{(}-1\right)(\alpha)$ is the inverse of the cumulative distribution function of the quantile of the standard normal distribution. Data in the financial sector often exhibit skewness and excessive tapering that indicate deviations from normality. If the data distribution is not normal, then the quantile value $(\alpha)$ to calculate the VaR value must be adjusted to the Cornish-Fisher expansion. (Rizani et al., 2019) show how to change for certain quantiles using skewness and excess kurtosis using the Cornish-Fisher expansion as follows:

with:

$$
a^{\prime}(\alpha)=a(\alpha)+\frac{S}{6}\left(a^{2}(\alpha)-1\right)+\frac{K-3}{24}\left(a^{3}(\alpha)-3 a(\alpha)\right)-\frac{S^{2}}{36}\left(2 a^{3}(\alpha)-5 a(\alpha)\right)
$$

a'= adjusted quantile

$\mathrm{a}=$ quantile in normal distribution

$\mathrm{S}=$ skewness coefficient

$\mathrm{K}=$ kurtosis coefficient.

So to calculate VaR, the following formula is obtained:

$$
\left.V \hat{a} R_{t}(\alpha)=\hat{\mu_{t}}+\hat{\sigma_{t}} F_{C} F^{(}-1\right)(\alpha)
$$

with $\left.F_{C} F^{(}-1\right)(\alpha)=$ the inverse of the cumulative distribution function of the th quantile using the Cornish-Fisher expansion.

Value at risk is calculated using the moving window concept on time series data to obtain the same basic model with optimal parameters. Each window consists of stock return data with time intervals of 250 days (1 transaction year), 375 days (1.5 transaction years), and 500 days ( 2 transaction years). The window will shift every one time interval so that the VaR parameter model estimation will be carried out in each window used. For example, in window 250 , there will be 250 data returns in each window. The first window is obtained from the $1^{\text {st }}$ data return to the $250^{\text {th }}$ data return, the second window is obtained from the $2^{\text {nd }}$ data return to the $251^{\text {st }}$ data return, and so on. 


\section{RESEARCH METHOD}

The study uses secondary data, which is the stock return data of PT. Bank Central Asia Tbk. (BBCA) and JCI were obtained from the finance.yahoo.com website, while the IDR/USD exchange rate data were obtained from the bi.go.id website. Data was conducted from January 3, 2017, to March 30, 2021.

The steps in the research are as follows:

1. Calculating the return of stock closing price data, the IDR/USD exchange rate, and JCI Stocks. The return is calculated by the following formula:

$$
R t=l\left(\frac{P t}{P t-1}\right)
$$

with is the stock's closing price at the time- $(t)$, and $P t-1$ is the stock's closing price at the time- $(t-1)$.

2. Calculating and analyzing descriptive statistical values on BBCA stock return data, IDR/USD exchange rate return data, and JCI stock return data.

3. Testing the stationarity of data.

4. Identify the ARIMAX model on BBCA stock returns as seen from the ACF and PACF plots.

5. Estimating and testing the significance of the ARIMAX model parameters with IDR/USD exchange rate returns and IHSG returns as exogenous variables.

6. Testing independence test and normality test on residual data.

7. Select the best ARIMAX model using the AIC criteria.

8. Identify the ARCH-GARCH effect on the residual value of the formed ARIMAX model.

9. Identify the ARIMAX-GARCHX model.

10. Estimating and testing the significance of the ARIMAX-GARCHX model parameters.

11. Perform an independence test and normality test on residual data.

12. Select the best ARIMAX-GARCHX model using the AIC criteria.

13. Calculating VaR based on the parameter estimation of the ARIMAX-GARCHX model with the first step is to detect deviations from the normal distribution by looking at the skewness and kurtosis values in the BBCA stock return data.

14. Determine the value of the confidence level (quantile) for the VaR calculation. If the BBCA stock return data has a standard normal distribution, the confidence level value used is 1.64. If the BBCA stock return data is not normally distributed, then the confidence level value is adjusted to the Cornish-Fisher expansion.

15. Calculating the estimated risk in each window 250, 375, and 500.

\section{RESULT AND DISCUSSION}

\section{Characteristics of Data}

In this study, Value-at-Risk (VaR) analysis was carried out using two approaches, namely the ARIMAX approach to estimate the mean parameter and the GARCHX approach to estimate the variance parameter. Before modeling, a correlation test was conducted to prove the theory regarding the effect of the IDR/USD exchange rate return and JCI return on the stock return of PT. Bank Central Asia Tbk.

Based on Table 1 , it can be seen that $H_{0}$ is rejected because it shows the results of $\left|t_{\text {value }}\right|>t_{0,05 ; 1015)}=1,96$ and $p-$ value $<0,05$. So it can be concluded that there is a relationship between exchange rate returns and BCA stock returns with a correlation value of $-0,109$, which means it has a negative correlation. There is also a relationship between IHSG returns and BCA stock returns with a correlation value of 0,572 , which means it has a positive correlation.

Table 1. Correlation Test Results

\begin{tabular}{ccccc}
\hline Correlation & $\begin{array}{c}\text { Correlation } \\
\text { Coefficient }\end{array}$ & $\left|t_{\text {value }}\right|$ & $p$-value & Decision \\
\hline $\begin{array}{c}\text { Exchange Rate and Stock } \\
\text { Return BCA }\end{array}$ & $-0,109$ & 3,495 & 0,000 & Reject $H_{0}$ \\
$\begin{array}{c}\text { JCI Return and BCA Stock } \\
\text { Return BCA }\end{array}$ & 0,572 & 22,263 & 0,000 & Reject $H_{0}$ \\
\hline
\end{tabular}


After that, we need to analyze the descriptive statistic. The characteristics of Bank Central Asia stock return data can be presented in Table 2.

Table 2. BBCA Stock Return Data Descriptive Statistics

\begin{tabular}{ll}
\hline Statistics & Value \\
\hline Mean & 0,000712 \\
Median & 0,000000 \\
Maximum & 0,159884 \\
Minimum & $-0,082444$ \\
Skewness & 0,742182 \\
Kurtosis & 15,486650 \\
\hline
\end{tabular}

The positive mean value indicates that BBCA stock tend to provide benefits to investors who invest. The skewness value is positive at 0,742182 which means that it has a right tail that is longer than its left tail. While kurtosis of more than 3 indicates that the curve formed is a leptokurtic curve and a fat tail. The results of skewness and kurtosis indicate that the BBCA stock return data is not symmetrically distributed.

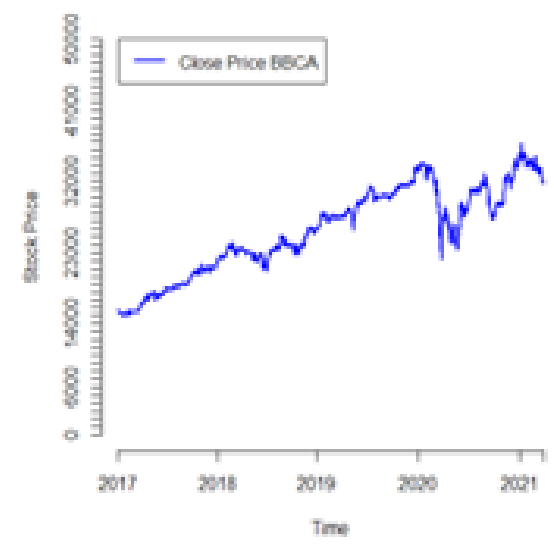

Figure 1. Plot Closing Price BBCA Stocks

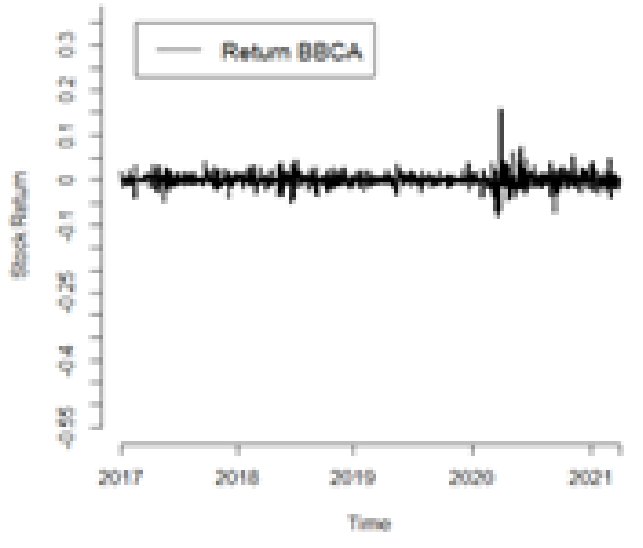

Figure 2. Plot Return BBCA Stocks

Figure 1 shows that the closing price data for Bank Central Asia stocks are not stationary because the plot shows an increase in value over time and decreases periodically at a certain point. The figure shows that the highest rise in stock prices occurred in early 2021 after experiencing price declines throughout early 2020. The decline in stock prices was caused by the Covid-19 pandemic, which affected the economy's pace in various countries, especially Indonesia. The fall occurred due to a decrease in the number of credit services. It was followed by a reduction in bank income due to government policies to carry out social distancing and lockdowns in several areas, which resulted in many business actors having difficulty running their business and potentially failing to pay the credit (Putri, 2020).

Meanwhile, the BBCA daily stock return closing price data plot shown in Figure 2 shows that the data is stationary in the mean. This is because the observed mean value is constant over time. The time series plot on the stock return data of Bank Central Asia also shows fluctuations in the data from time to time which causes stock returns to have volatility which causes cases of heteroscedasticity.

Testing the stationarity of the data visually is not enough to determine whether the data is stationary. So it is necessary to do a formal test to make a decision whether the data is really stationary. The test used is the Augmented Dickey-Fuller. The results of stationarity testing on BBCA stock return data and the two exogenous variables are summarized in Table 3. 
Table 3. Augmented Dickey-Fuller Test

\begin{tabular}{lcccc}
\hline Variabel & Lag & $A D F_{\text {value }}$ & $p-$ value & Decision \\
\hline BBCA Stock Return & 10 & $-11,229$ & 0,01 & Reject $H_{0}$ \\
IDR/USD Exchange Rate Return & 10 & $-7,710$ & 0,01 & Reject $H_{0}$ \\
JCI Stock Return & 10 & $-9,999$ & 0,01 & Reject $H_{0}$ \\
\hline
\end{tabular}

The results obtained based on the table are the three return data are formally stationary because they show $p-v a l u e<0,05$ and $A D F_{\text {value }}<A D F_{1017 ; 0,05}=-2,86$. So that the three data can be continued for further analysis.

\section{Identification of ARIMAX Model}

The identification of the ARIMAX model was carried out using the ACF plot for determine the order of $q$ and plot the PACF to determine the order of $\mathrm{p}$ that can be seen from Figure 3.

Return BBCA

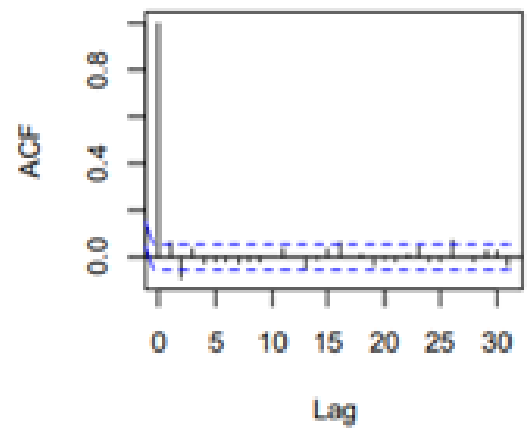

Return BBCA

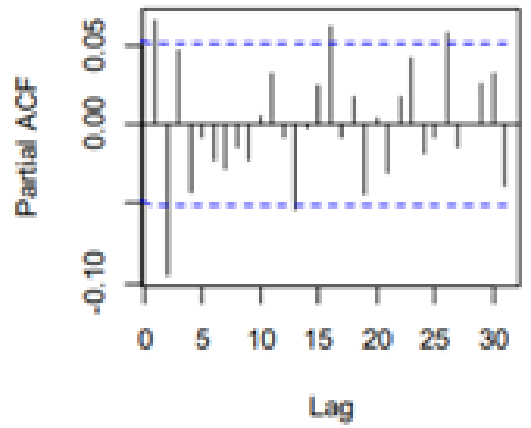

Figure 3. ACF and PACF Plots of BBCA Stock Returns

Based on the ACF and PACF plots, it can be seen that the ACF. Plot truncated at lags 1,2,16, and 26, while the PACF plot was truncated at lag 1,2,13,16, and 26. In this study, ARIMAX modeling is based on the parcimony principle, which states that the estimation of a model is attempted using the simplest possible model. The best model is the simplest model. So that the possible ARIMAX model for BBCA stock return data which is influenced by exogenous variables, namely return the IDR/USD exchange rate and JCI returns are $\operatorname{ARIMAX}(1,0,1,2), \operatorname{ARIMAX}(1,0,2,2), \operatorname{ARIMAX}(2,0,1,2)$ and $\operatorname{ARIMAX}(2,0,2,2)$.

After identifying the model, estimating and testing the significance of the parameters, and diagnostic checking, the next step is to choose the best ARIMAX model with the AIC value criteria. The ARIMAX model, which has the smallest AIC value, is ARIMAX (2,0,1,2), where the significant exogenous variable are IDR/USD exchange rate return and JCI return.

\section{Identification of the ARCH/GARCH Effect}

The next test is the lagrange multiplier test; this test is carried out to determine whether there is an ARCH/GARCH effect or a heteroscedasticity effect on the residual ARIMAX model formed. The results obtained are that H0 is rejected because the value of $L M>\chi_{(0,05, m)}^{2}$ in each lag and $p-$ value $=0<=0,05$. So, at the $5 \%$ significance level, it can be concluded that there is a heteroscedasticity effect on the residuals, so the $\operatorname{ARIMAX}(2,0,1,2)$ model can be continued with GARCHX modeling.

\section{Identification of GARCHX models}

Identifying the GARCHX model can do by looking at the ACF and PACF plots formed from the results of the residual square of BCA stock return data. The ACF and PACF plot can be seen from Figure 4. 
BBCA

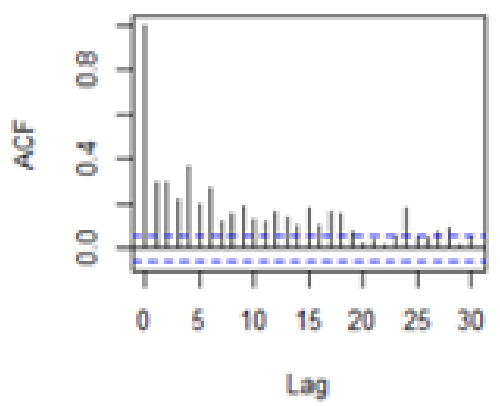

BBCA

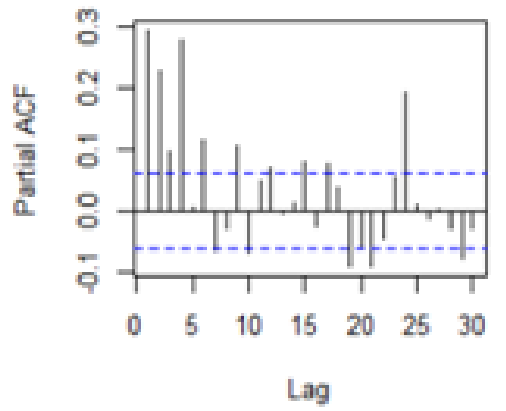

Figure 4. ARIMAX Square Residual ACF and PACF Plots $(2,0,1,2)$

Based on parcimony principle, model identification BBCA's initial stock returns are GARCHX $(1,1,2)$, GARCHX $(1,0,2)$ and GARCHX $(0,1,2)$. So, we get the initial model to calculated the VaR, namely $\operatorname{ARIMAX}(2,0,1,2)$ $\operatorname{GARCHX}(1,1,2), \operatorname{ARIMAX}(2,0,1,2)-\operatorname{GARCHX}(1,0,2)$ and $\operatorname{ARIMAX}(2,0,1,2)-\operatorname{GARCHX}(0,1,2)$.

\section{Estimation and Significance Test of the ARIMAX-GARCHX Model Parameter}

After all the tests are met, the best model is selected by looking at the smallest AIC value. The best model obtained is ARIMAX(2,0,1,2)-GARCHX $(1,1,2)$. The three models were estimated and tested for parameter significance as well as diagnostic checking. After all the tests are met, the best model is selected by looking at the smallest AIC value. The best model obtained is $\operatorname{ARIMAX}(2,0,1,2)-\operatorname{GARCHX}(1,1,2)$. The estimation and significance test of the best model is shown in Table 4, significance hypothesis testing can be done as follows:

$H_{0}: \varnothing_{i}=0$ (parameter is not significant to the model)

$H_{1}: \varnothing_{i} \neq 0, i=1,2, \ldots, p$ (parameter is significant to the model)

with the significant level used is $=0.05$. The test criteria is that $\mathrm{H} 0$ is rejected if $|t|>t_{\left(\frac{\alpha}{2} ; n-p\right)}$ or $p-$ value $<\alpha$.

Table 4. Estimation and Significance Test of ARIMAX(2,0,1,2)-GARCHX(1,1,2)

\begin{tabular}{ccrrrrr}
\hline Model & Parameter & Coefficient & $t_{\text {value }}$ & $t_{\text {tabel }}$ & $p$-value & Decision \\
\hline & $\mu$ & 0,0008 & 4,5573 & 1,9623 & 0,0000 & Reject $H_{0}$ \\
& $\varnothing_{1}$ & 0,7525 & 10,6756 & 1,9623 & 0,0000 & Reject $H_{0}$ \\
& $\varnothing_{2}$ & 0,0812 & 2,2299 & 1,9623 & 0,0258 & Reject $H_{0}$ \\
ARIMAX & $\theta_{1}$ & $-0,9133$ & $-16,2869$ & 1,9623 & 0,0000 & Reject $H_{0}$ \\
$(2,0,1,2)-$ & $\bar{\omega}_{1}$ & 0,1248 & 1,3851 & 1,9623 & 0,166 & Accept $H_{0}$ \\
GARCHX & $\bar{\omega}_{2}$ & 0,9537 & 24,9374 & 1,9623 & 0,0000 & Reject $H_{0}$ \\
$(1,1,2)$ & $\omega$ & 0,000001 & 31,498 & 1,9623 & 0,0000 & Reject $H_{0}$ \\
& $\alpha_{1}$ & 0,0606 & 6,1048 & 1,9623 & 0,0000 & Reject $H_{0}$ \\
& $\beta_{1}$ & 0,8975 & 87,2978 & 1,9623 & 0,0000 & Reject $H_{0}$ \\
& $\phi_{1}$ & 0,001 & 3,1059 & 1,9623 & 0,0019 & Reject $H_{0}$ \\
& $\phi_{2}$ & 0,0000 & 0,0000 & 1,9623 & 1,0000 & Accept $H_{0}$ \\
\hline
\end{tabular}

Based on this table, the ARIMAX(2,0,1,2)-GARCHX(1,1,2) model has significant parameters, where the significant exogenous variable in the ARIMAX model is the JCI return while the GARCHX model is the IDR/USD exchange rate return. So the mathematical model is written as follows:

$$
\begin{aligned}
& \hat{Z}_{t}=0,0008+0,7525 Z_{t-1}+0,0812 Z_{t-2}+a_{t}+0,9133 a_{t-1}+0,9537 X_{2, t} \\
& \hat{\sigma}_{t}^{2}=0,000001+0,0606 a_{t-1}^{2}+0,8975_{t-1}^{2}+0,0010 X_{1, t}^{2}
\end{aligned}
$$




\section{Calculation of Value-at-Risk}

The VaR calculation uses Cornish-Fisher expansion according to Equation (8) because of skewness and kurtosis, which shows deviation from normality. Based on the analyses performed, the obtained is $-1,39$, which means that the Cornish-Fisher expansion produces a value greater than the standard normal quantile $(-1,64)$. The level of confidence used to calculate VaR is 95\%. The BBCA stock risk estimation results using VaR calculations with a window of 250 days, 375 days, and 500 trading days are shown in Table 5.

Table 5. Risk Estimation Results

\begin{tabular}{cc}
\hline Window & Risk \\
\hline 250 & 0,0137 \\
375 & 0,0138 \\
500 & 0,0140 \\
\hline
\end{tabular}

The maximum loss can be calculated by multiplying the investment amount by the level of risk. Based on Table 5, it can be seen that using a window of 500 transaction days can provide the most significant maximum estimated loss. In the 500 day window, there is a 95\% probability that an investor will invest in PT. Bank Central Asia Tbk. of Rp. 1.000.000.000,- will suffer a maximum loss of Rp. 14.000.000,-

\section{E. CONCLUSION AND SUGGESTION}

Based on the results and discussion of the Value-at-Risk calculation using the ARIMAX-GARCHX model approach on BBCA stocks for the period from January 3, 2017 to March 30, 2021, the following conclusions are obtained; The best model for modeling BBCA stock returns is ARIMAX(2,0,1,1)-GARCHX(1,1,1), where the significant exogenous variable in the ARIMAX model is the JCI return while the GARCHX model is the IDR/USD exchange rate return. The calculation of the VaR value at the $95 \%$ confidence level based on the window that produces the largest VaR value estimate, it is known that the possibility of an investor investing in the company PT. Bank Central Asia Tbk. of Rp. 1.000.000.000,- will suffer a maximum loss of Rp. 14.000.000,-.

\section{REFERENCES}

Azmi, U. and Syaifudin, W. H. (2020). Peramalan Harga Komoditas Dengan Menggunakan Metode Arima-Garch. Jurnal Varian, 3(2):113-124.

Bursa Efek Indonesia (2021). Pengembangan Pasar Modal Indonesia: Apresiasi BEI untuk Negeri di Tahun Kebangkitan Investor Ritel Dalam Negeri.

Darsyah, M. Y. and Nur, M. S. (2016). Model Terbaik Arima Dan Winter Pada Peramalan Data Saham Bank. Jurnal Statistika, 4(1):30-38.

Guha, B. and Bandyopadhyay, G. (2016). Gold Price Forecasting Using ARIMA Model. Journal of Advanced Management Science, (March):117-121.

Made, G. A., Putri, A., Putu, N., Hendayanti, N., and Nurhidayati, M. (2017). Pemodelan Data Deret Waktu Dengan Autoregressive Integrated Moving Average Dan Logistic Smoothing Transition Autoregressive Gusti Ayu Made Arna Putri. Jurnal Varian, $1(1): 54$

Messaoud, S. B. and Aloui, C. (2015). Measuring risk of portfolio: GARCH-copula model. Journal of Economic Integration, 30(1):172-205.

Prastyo, D. D., Handayani, D., Fam, S. F., Rahayu, S. P., Suhartono, and Satyaning Pradnya Paramita, N. L. P. (2018a). Risk evaluation on leading companies in property and real estate subsector at IDX: A Value-at-Risk with ARMAX-GARCHX approach and duration test. Journal of Physics: Conference Series, 979(1).

Prastyo, D. D., Sudjati, I. L., Fam, S. F., Setiawan, Suhartono, and Satyaning Pradnya Paramitaa, N. L. P. (2018b). Value-at-Risk Modeling on Stock Return with Exogenous Variables using ARMAX-GARCHX Approach. Journal of Physics: Conference Series, 1028(1). 
Primajati, G. (2018). Analisis Portofolio Investasi Pada Saham Lq45 Dengan Metode Mean Varian Satu Konstrain. Jurnal VARIAN, $1(2): 22-29$.

Puspatika, K. and Kusumawati, Y. (2018). Peramalan Harga Cabai Dengan Metode Arima Arch- Garch Dan Single Moving Average Di Kota Semarang. Journal JOINS Udinus, 03(02):192-201.

Putri, H. T. (2020). Covid 19 dan Harga Saham Perbankan di Indonesia. Eksis: Jurnal Ilmiah Ekonomi dan Bisnis, 11(1):6.

Ratih, I. D., Ulama, B. S. S., and Prastuti, M. (2018). Value at Risk Analysis Using ARMAX GARCHX Approach for Estimating Risk of Banking Subsector Stock Return's. Journal of Physics: Conference Series, 974(1).

Rizani, N. F., Mustafid, and Suparti (2019). Penerapan Metode Expected Shortf All pada Pengukuran Risiko Investasi Saham dengan Volatilitas Model Garcg. Jurnal Gaussian, 8(2):12-26.

Tyas, M. D. P., Maruddani, D. A. I., and Rahmawati, R. (2019). Perhitungan Value At Risk Dengan Pendekatan Threshold Autoregressive Conditional Heteroscedasticity-Generalized Extreme Value. Media Statistika, 12(1):73. 
